\title{
化学分解性界面活性剂の開発
}

\section{Development of Chemocleavable Surfactants}

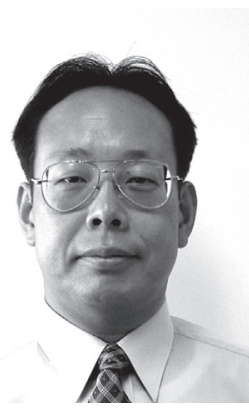 \\ 小野 大助 \\ 大阪市立工業研究所 生物・生活材料研究部 \\ 香粧品材料研究室 \\ 干 536-8553 \\ 大阪市城東区森之宮 1-6-50 \\ Daisuke ONO \\ Cosmetic Materials Lab, Biomaterial and \\ Commodity Chemicals Research Division, \\ Osaka Municipal Technical Research Institute \\ 1-6-50 Morinomiya, Joto-ku, Osaka 536-8553, Japan
}

論文要旨: 界面活性剤は, 洗剤, 塗料, トイレタリーや医薬品など様々な用途で利用されている。最近で は, より優れた界面物性を有する界面活性剤, 二次的な機能を有する複合機能型活性剂, あるいは, 地球環 境保全に配慮を加えた活性剤などの開発が望まれている。このため, 界面活性剤としての本来の機能を果し た後, 酸や光などのできるだけ温和な外的因子を引き金として分解が起こり界面活性能が消失する機能を備 えた化学分解性界面活性剂の開発に興味がもたれている。本稿では, 1-O-アルキルグリセロールから 1,3- ジ オキソラン環を分子内に有する酸分解性カルボン酸塩型界面活性剂とエステル型化学分解性界面活性剂を特 殊な試薬や装置を用いることなく, 簡便な操作により合成した。これらは, 良好な界面物性を有し, 酸性ま たはアルカリ条件下で, 非界面活性成分に分解した。また, 微生物による生分解性は, ドデカン酸ナトリウ ムよりも優れていた。乳化重合反応で乳化剤として用いた場合, 反応終了後, 酸またはアルカリを添加する ことにより, 乳化系を解消でき塩濃度の低い純度の高いポリマーを容易に単離することができた。さらに, 洗浄力についても検討した。

\begin{abstract}
Surfactants are used in many applications, such as detergents, paints, toiletries and pharmaceuticals. The development of surfactants with excellent surface-active properties, additional functions, or good biodegradability has been desired. Therefore, chemocleavable surfactants, which decompose to give nonsurface-active species or other surfactants with different properties after fulfilling their original functions, have become the focus of great interest in the field of surfactant chemistry. In this review, chemocleavable surfactants bearing a 1,3-dioxolane ring or ester group were prepared from 1-O-alkylglycerols without any expensive reagents or special equipment. We clarified that they have good surface-active properties, and the decomposition function under acid or alkali conditions. Their biodegradabilities were higher than that of sodium dodecanoate. We used these surfactants as emulsifiers in emulsion polymerization. After the reaction, the emulsifier was decomposed by the addition of $\mathrm{HCl}$ or $\mathrm{NaOH}$. And then the polymer was obtained easily. We discussed their detergency for clothes.

Key words: Chemocleavable surfactant, 1-O-alkylglycerols, Biodegradation, Detergency, Emulsion polymerization
\end{abstract}

\section{1 はじめに}

界面活性剂は, 洗剤や香粧品に使用されるように最も 身近な化学物質の 1 つであるとともに, 多岐にわたる工 業分野において様々な用途で利用されており, 産業活動 を表裏から支える重要な機能性物質である。最近では,

連絡者: 小野 大助

E-mail :daiskono@omtri.or.jp
より優れた界面物性を有する界面活性剂, 二次的な機能 を有する複合機能型活性剤, あるいは, 地球環境保全に 配慮を加えた活性剤などの開発が望まれている。有機反 応や高分子合成の分野では，界面活性剤集合体は有用な 反応媒質の 1 つである。しかし, 乳化系のままでは反応 生成物の単離が困難であったり, 反応物中に界面活性剂 が残存していると生成物の品質が低下するなどの問題点 がある。このため, 乳化, 可溶化, ミセル触媒のような 
界面活性剂としての本来の機能を果した後，酸や光など のできるだけ温和な外的因子を引き金として分解が起こ り界面活性能が消失する機能を備えた化学分解性界面活 性剂の開発に興味がもたれている。例えば，乳化重合に 適した分解性活性剂が開発できれば，重合反応終了後， 活性剤を分解させることにより乳化系がすみやかに解消 され，目的ポリマーの単離が極めて容易になり，製造効 率と製品純度を向上させることが可能となる。また，洗 浄剂として用いた場合, 使用後, 分解することにより有 機物を大部分除去できるので，排水処理が容易となる。 これまで主に系の $\mathrm{pH}$ を調整することにより分解可能な アセタール型，1,3-ジオキソラン型，1,3- ジオキサン型 の化合物が開発されてきた ${ }^{1-7)}$ 。

我々も，天然物由来品あるいは容易に入手可能である 工業製品を出発物質として用い，できるだけ簡便な操作 で効率良く合成することを念頭に置き，酸あるいはアル カリに応答して分解する新しい界面活性剤の開発に取り 組んでいる。これまでにアセタール基，1,3- ジオキソラ ン環やエステル基を有するさまざまな種類の化学分解性 界面活性剤を開発してきた ${ }^{8-20)}$ 。また，これらの分解性 活性剂の水溶液系での界面物性を測定し，通常型の界面 活性剂と比較を行い，新たに組み込まれた分解性連結部 構造（アセタール基，1,3-ジオキソラン環，エステル基） の界面物性に及ぼす効果を明らかにした。さらに，水溶 液中での化学分解性を測定し, 末端親水性官能基の構造 と分解速度の関係を明らかにした ${ }^{8,9)}$ 。また，最近では エコロジーの観点から生分解性の優れた界面活性剂が望 まれており，いくつかの分解性界面活性剂の生分解性に ついて検討し，通常の界面活性剂と同等以上であること を明らかにした ${ }^{13,15-19)}$

本稿では，合成の容易なオレオケミカルズである 1-Oアルキルグリセロールから 1,3- ジオキソラン環を分子内
に有する酸分解性カルボン酸塩型界面活性剤と酸にもア ルカリにも応答するエステル結合を分解性部位として組 み込んだ，分解性ビス（スルホン酸塩）型界面活性剂を 合成し (Scheme 1), 基本的な界面物性と化学分解性に 加えて活性污泥による生分解性について検討し, さらに, 実用化を指向して，洗浄力ならびに乳化重合用乳化剂と して応用したので紹介する $\left.{ }^{10}, 13,15,20\right) 。$

\section{1,3- ジオキソラン環及びエステル型化学分解性界面 活性剂の合成}

目的物は，1-O-アルキルグリセロールを出発物質とし て，特殊な試薬や装置を用いることなく簡便な操作によ り合成できることを見出した。1-O-アルキルグリセロー ルは，天然物由来品あるいはオレオケミカルズ製品とし て種々のタイプのものが入手可能であり ${ }^{21-23)}$ ，それ自 身が香粧品基材 ${ }^{24,25)}$ などとして用いられる。

1,3-ジオキソラン型分解性活性剂 1 は, トルエン中, p-トルエンスルホン酸存在下, オキソ酸エチルと脱水縮 合させ 1,3- ジオキソラン環を有する中間体化合物を合成 し, 次にメタノール中, 等量の水酸化ナトリウムでアル カリ加水分解することにより高収率で得た。中間体化合 物は, クーゲルロール蒸留により単離した。へキサデシ ルやオクタデシル基を有する分解性活性剂 1 は, エ夕 ノールからの再結晶により単離し,他の目的物 1 は, ワッ クス状のため, メタノールを溶離液とした逆相カラムク ロマトグラフィーにより精製した ${ }^{10)}$ 。

エステル型分解性活性剂 2 は, 1-O-アルキルグリセ ロールとブロモカルボン酸とのエステル化反応で中間体 $\alpha$-ブロモエステルをほぼ定量的に合成し，そのまま精 製せず，亜硫酸ナトリウムとの改良 Strecker 反応によ り合成した。本反応は，触媒量の硫酸水素テトラブチル アンモニウムを添加することにより，通常の Strecker

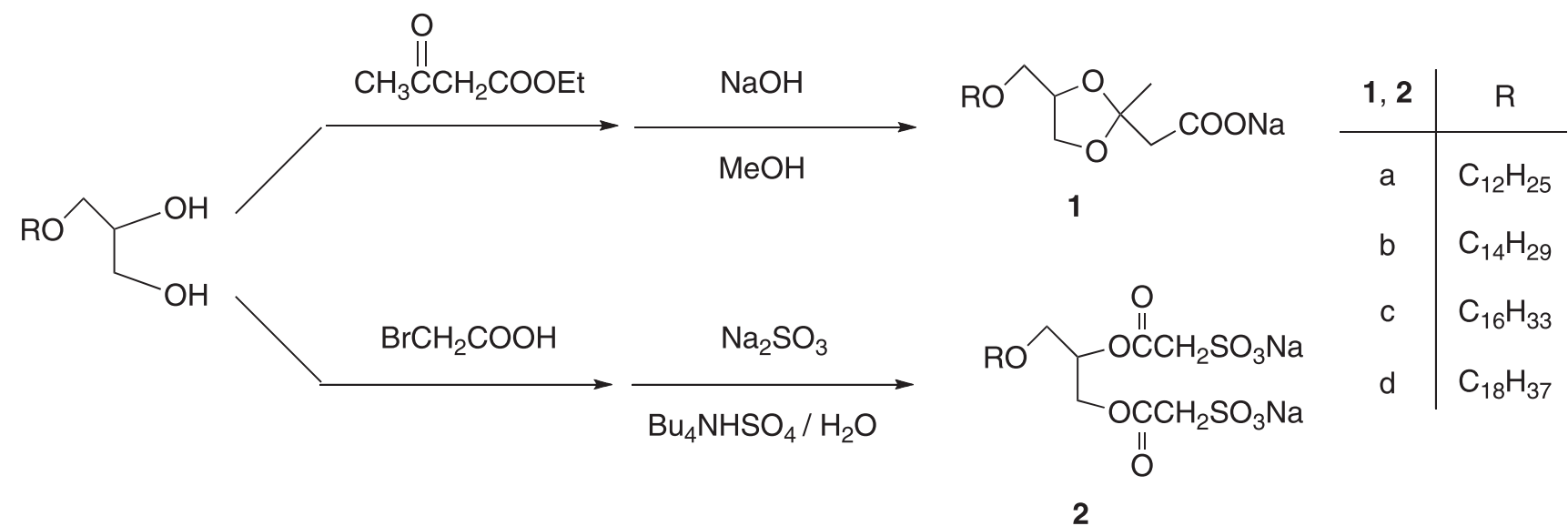

Scheme 1 Preparation of chemocleavable surfactants from 1-O-alkylglycerols 
反応より低温，短時間で反応が進行した。反応後，熱メ タノールで不溶分をろ別し，溶媒を留去後，白色個体を エタノールで洗い目的物 2 を得た ${ }^{15)}$ 。

\section{3 化学分解性界面活性剂の界面物性}

\section{$3 \cdot 1$ 基本的界面物性の測定}

Fig. 1 にウイルヘルミー法により測定した表面張力ー 濃度曲線を通常型界面活性剤と共に示した。Table 1 に 分解性活性剂 1，2 のクラフト点 $\left(T_{\mathrm{Kp}}\right)$, 臨界ミセル濃 度 $(\mathrm{cmc})$, 表面張力低下能 $\left(\gamma_{\mathrm{cmc}}\right), \mathrm{Gibbs}$ の式から計
算した表面吸着占有面積 (A ${ }^{26)}$ の結果を同条件下で測 定したドデカン酸ナトリウムとドデカンスルホン酸ナト リウムの值と共にまとめた。

分解性活性剂 1，2 は, 2c 以外, $1 \mathrm{wt} \%$ 水溶液の $T_{\mathrm{Kp}}$ が $0^{\circ} \mathrm{C}$ 以下であり水溶性は良好であった。分解性活性剂 1 は，典型的な石けんの中では比較的水に溶けやすいド デカン酸ナトリウムより高い水溶性を示した。それは, ジオキソラン環や側鎖のエーテル酸素が水溶性の向上に 貢献しているためと考えられる。ドデシル基を有する分 解性活性剤 $1 \mathrm{a}$ の $\mathrm{cmc}$ 值は, ドデカン酸ナトリウムに比

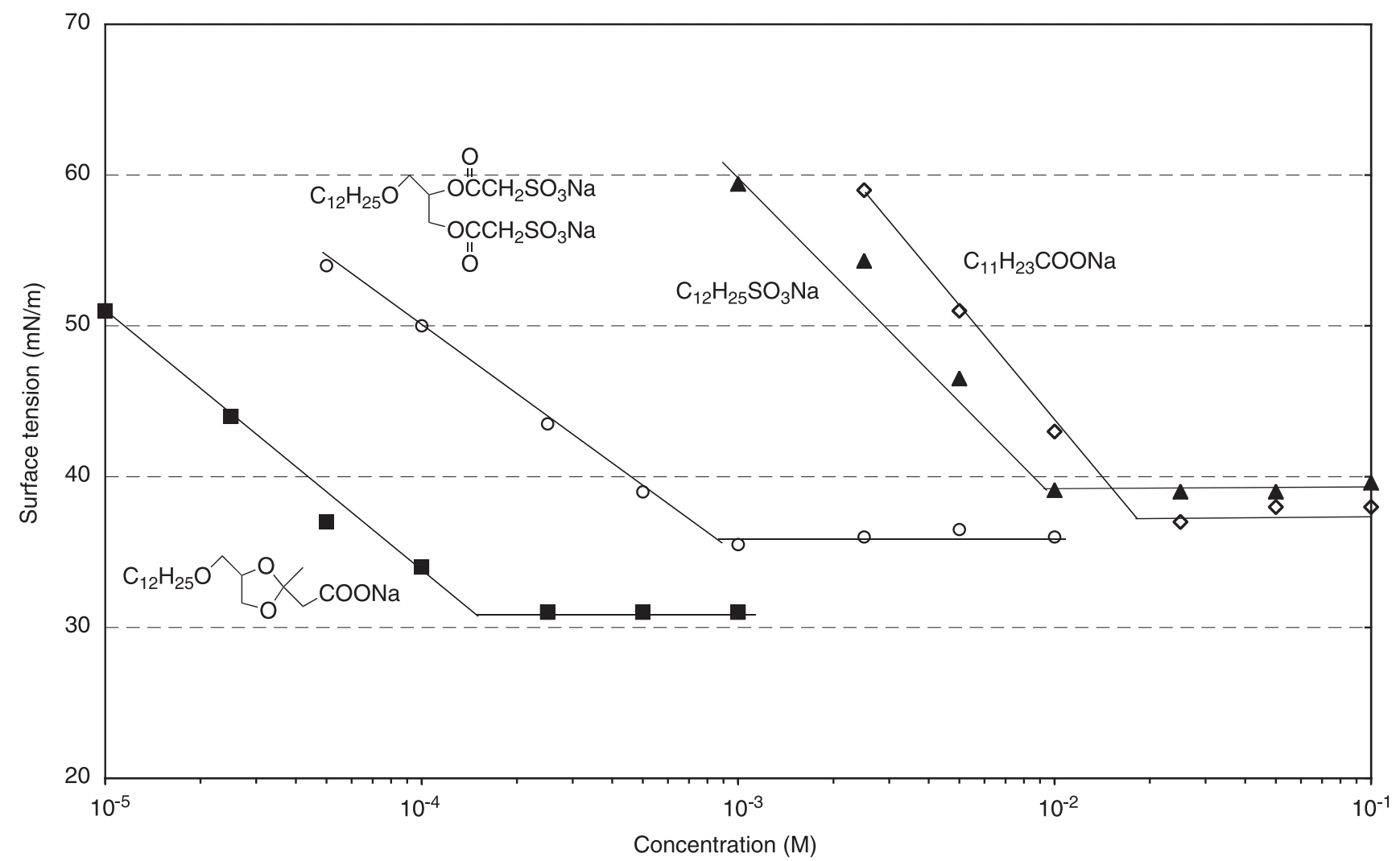

Fig. 1 Surface tension-concentration plots of chemocleavable surfactants 1, 2 .

Table 1 Surface-active properties for chemocleavable surfactants $1,2^{\mathrm{a})}$

\begin{tabular}{|c|c|c|c|c|c|}
\hline \multicolumn{2}{|c|}{ Compound } & $\begin{array}{l}T_{\mathrm{Kp}}{ }^{\mathrm{b})} \\
\left({ }^{\circ} \mathrm{C}\right) \\
\end{array}$ & $\begin{array}{l}10{ }^{3} \mathrm{cmc} \\
(\mathrm{mol} / \mathrm{L})\end{array}$ & $\begin{array}{c}\gamma_{\mathrm{cmc}} \\
(\mathrm{mN} / \mathrm{m})\end{array}$ & $\begin{array}{l}10^{2} \mathrm{~A} \\
\left(\mathrm{~nm}^{2}\right)\end{array}$ \\
\hline $1 \mathrm{a}$ & $\mathrm{C}_{12} \mathrm{H}_{25}$ & $<0$ & 0.16 & 31.0 & 113 \\
\hline $1 c$ & $\mathrm{C}_{16} \mathrm{H}_{33}$ & $<0$ & 0.0076 & 34.5 & 98 \\
\hline $2 a$ & $\mathrm{C}_{12} \mathrm{H}_{25}$ & $<0$ & 0.90 & 36.0 & - \\
\hline $2 c$ & $\mathrm{C}_{16} \mathrm{H}_{33}$ & 17 & 0.052 & 36.2 & - \\
\hline \multicolumn{6}{|c|}{ (Reference: Typical surfactant) } \\
\hline \multicolumn{2}{|c|}{$\mathrm{C}_{11} \mathrm{H}_{23} \mathrm{COONa}$} & 19 & 20 & 37.5 & 69 \\
\hline \multicolumn{2}{|c|}{$\mathrm{C}_{11} \mathrm{H}_{23} \mathrm{SO}_{3} \mathrm{Na}$} & 38 & 9.8 & 39.0 & - \\
\hline
\end{tabular}

a) At $25{ }^{\circ} \mathrm{C}$

b) At $1 \mathrm{wt} \%$. 
ベ, 約 2 ケ夕小さく, ミセル形性能に優れていた。分解 性活性剂 1 の $\gamma_{\mathrm{cmc}}$ 值は, ドデカン酸ナトリウムよりも小 さかった。活性剤 1 の表面吸着占有面積（A）は，ジオ キソラン環のかさ高さが影響するためドデカン酸ナトリ ウムに比べて大きくなった。また，一般の活性剤と同様 にアルキル鎖長が大きくなると水の表面に吸着した活性 剂分子間の疎水基相互作用が増大するため， A 值は小 さくなった ${ }^{26)}$ 。

分解性活性剂 2 の $\mathrm{cmc}$ 值は，通常の界面活性剂であ るドデカンスルホン酸ナトリウムの約 10 分の 1 以下で あり，少量で性能を発揮することがわかった。一般的に かさ高い疎水基や親水基を持つ界面活性剤はそうでない ものより $\mathrm{cmc}$ が増大することが多い ${ }^{26)}$ 。しかし, 本研 究の分解性活性剂 2 は分子内に 2 つ親水基を有する にもかかわらず，通常の界面活性剤より非常に小さい $\mathrm{cmc}$ 值を示した。その理由として, 次の 2 つの可能性 を考えている。1つは，これらの分解性活性剤は同じア ルキル鎖を有する典型的な界面活性剤に比べ分子内の全 炭素数が多く, その結果疎水性が増して, $\mathrm{cmc}$ が低くなっ た。もう 1 つは, 2 つ親水基は非常に接近しているため, 電気反発により解離が制限されて，そのため親水基のか さ高さが軽減され，2つの親水基が存在してもミセル形 成にあまり影響しなかった。 $\gamma_{\mathrm{cmc}}$ は，アルキル鎖長との 間に明確な相関関係は認められなかったが, ドデカンス ルホン酸よりも小さかった。一連の分解性活性剤 2 は,
一鎖二親水基型にもかかわらず優れたミセル形成能と低 い $\gamma_{\mathrm{cmc}}$ を示した。

分解性活性剂 1，2 の泡物性と耐硬水性の結果を通常 の界面活性剂の值と共に Table 2 に示した。起泡力・泡 末安定性は, 半微量 TK 法で ${ }^{27)}$, 耐硬水性を改良 Hart 法により評価した ${ }^{28,29)}$ 。

分解性活性剂 1, 2 は, 起泡力. 泡末安定性ともに通 常の界面活性剤よりも優れていた。

耐硬水性は，典型的なカルボン酸ナトリウムの場合， 不溶のカルシウム石けんが, ドデカン酸ナトリウムで $250 \mathrm{ppm}$ ( $\mathrm{CaCO}_{3}$ 換算)，オレイン酸ナトリウムで 340 ppm で沈殿しはじめた。これらの結果と比較して, 分 解性活性剂 1a は, $500 \mathrm{ppm}$ 以上でも水に可溶であった。 このことから，1,3- ジオキソラン環が耐硬水性を向上さ せる効果のあることが明らかとなった。

分解性活性剂 2 の耐硬水性は，一鎖二親水基型であ るため, すべてで $2000 \mathrm{ppm}$ 以上と非常に優れた值を示 し，ドデカンスルホン酸ナトリウムの $200 \mathrm{ppm}$ と比較 した場合，10 倍以上であることがわかった。

\section{$3 \cdot 2$ 酸及びアルカリ添加による化学分解性}

ドデシル基を有する分解性活性剂 $1 \mathrm{a}, 2 \mathrm{a} 0.02 \mathrm{M} \mathrm{D}_{2} \mathrm{O}$ 中での酸，アルカリ分解特性を ${ }^{1} \mathrm{H}$ NMRにより検討し た ${ }^{10,15)}$ 。Table 3 には, 酸, アルカリ条件下で分解性活 性剤が完全に分解するのに要した時間を示した。

その結果, 分解性活性剂 1aは, 酸性条件下, $1 \mathrm{M}$ で

Table 2 Foaming properties and solubility in hard water for chemocleavable surfactants 1,2 .

\begin{tabular}{|c|c|c|c|c|c|}
\hline \multicolumn{2}{|c|}{ Compound } & \multicolumn{3}{|c|}{ Foam volume $(\mathrm{mL})^{\mathrm{a})}$} & \multirow{2}{*}{$\begin{array}{l}\text { Solubility in hard } \\
\text { water }^{\mathrm{b})}(\mathrm{ppm})\end{array}$} \\
\hline & $\mathrm{R}$ & $0^{\prime}$ & $1^{\prime}$ & $5^{\prime}(\min )$ & \\
\hline $1 a$ & $\mathrm{C}_{12} \mathrm{H}_{25}$ & 260 & 260 & 260 & 500 \\
\hline $1 c$ & $\mathrm{C}_{16} \mathrm{H}_{33}$ & 260 & 260 & 260 & - \\
\hline $2 a$ & $\mathrm{C}_{12} \mathrm{H}_{25}$ & 260 & 260 & 260 & $>2000$ \\
\hline $2 c$ & $\mathrm{C}_{16} \mathrm{H}_{33}$ & 260 & 260 & 260 & $>2000$ \\
\hline \multicolumn{6}{|c|}{ (Reference: Typical surfactant) } \\
\hline \multicolumn{2}{|c|}{$\mathrm{C}_{11} \mathrm{H}_{23} \mathrm{COONa}$} & 200 & 200 & 190 & 250 \\
\hline \multicolumn{2}{|c|}{$\mathrm{C}_{11} \mathrm{H}_{23} \mathrm{SO}_{3} \mathrm{Na}$} & 215 & 190 & 130 & 200 \\
\hline
\end{tabular}

a) At $25^{\circ} \mathrm{C}, 0.1 \mathrm{wt} \%$.

b) These values are the maximal total hardness as $\mathrm{CaCO}_{3}$ of hard water in which a $0.5 \mathrm{wt} \%$ of the compound can dissolve.

Table 3 Decomposition profiles of chemocleavable surfactants 1,2 at $25^{\circ} \mathrm{C}^{\text {a) }}$.

\begin{tabular}{cccccc}
\hline Compound & \multicolumn{3}{c}{ Time for complete decomposition } \\
& \multicolumn{3}{c}{$\mathrm{NaOD}$} & & \multicolumn{2}{c}{$\mathrm{DCl}$} \\
\cline { 2 - 3 } \cline { 5 - 6 } \cline { 5 - 6 } & $0.1 \mathrm{M}$ & $0.01 \mathrm{M}$ & & $1 \mathrm{M}$ & $0.5 \mathrm{M}$ \\
\hline 1a & - & - & & Immediately & $30 \mathrm{~min}$ \\
$\mathrm{nnnnyyy}$ & Immediately & $45 \mathrm{~min}$ & & 2 day & 3 day \\
\hline
\end{tabular}

a) Determined by the ${ }^{1} \mathrm{H}$ NMR measurement. 
添加直後, $0.5 \mathrm{M}$ では, 約 30 分でほぼ完全に分解する ことがわかった。しかし, pH 3 の酸性条件下では，分 解性活性剂 1 は遊離酸の状態で少なくとも 1 週間以上 は安定であり，1,3- ジオキソラン環の加水分解は認めら れなかった。

分解性活性剂 2aは, アルカリ条件の場合, $0.1 \mathrm{M}$ で 添加直後， $0.01 \mathrm{M}$ で，45 分後に分解した。酸性条件の 場合, アルカリ条件に比べ分解は遅く, $1 \mathrm{M}$ で 2 日, $0.5 \mathrm{M}$ では 3 日かかった。

さらに，分解性活性剂 1，2 をそのまま保存した場合, 少なくとも 1 年は安定であることを確認した。

\section{$3 \cdot 3$ 微生物による生分解性}

生分解性は, BOD (生物化学的酸素要求量) 測定法 によって評価した。実験は，「化学物質の審査および製 造等の規制に関する法律」（化審法）に規定された「微 生物による化学物質の分解度試験」に準拠した。試験溶 液は，JIS K0102 に定められた基礎培養基に，試料と活 性污泥（大阪市下水処理場または標準活性污泥）を，そ れぞれ $100 \mathrm{ppm}(\mathrm{w} / \mathrm{v})$ と $30 \mathrm{ppm}(\mathrm{w} / \mathrm{v})$ となるよう に調製した。クーロメータで試験溶液を $25^{\circ} \mathrm{C} て ゙ ~ 14$ 日間 または 28 日間培養し，系の BOD の変化を経時的に測 定した。Fig. 2 に，分解性活性剤 1a，2aの 2 週間後の
生分解性の結果を，同条件下で測定した通常の界面活性 剂の結果と共に示した ${ }^{13,15)}$

分解性活性剂 1a，2a ともに2 週間後の生分解性は約 60\%と優れていた。通常の界面活性剂と比べた場合，こ れらの分解性界面活性剂は，ドデカンスルホン酸ナトリ ウムや洗剤の主要配合成分の LASより優れており，ド デカン酸ナトリウムと同等以上であった。また, 出発物 質でありまた分解後の成分でもある 1-O-ドデシルグリ セロールは，もとの分解性活性剂 1a，2aよりも優れた 生分解性を示した。

以上より，これらの分解性活性剂の生分解性は，LAS はもちろん, 生分解性が良いと評価されているドデカン 酸ナトリウムをも上回る高い生分解性を備えていること が分かった。さらに，これらの活性剤が加水分解を受け て生じるフラグメントでもある1-O-ドデシルグリセ ロールは, さらに一段と生分解性が高く, 活性剂の使用 後, 系を予酸加水分解する行程を加えるならば, 環境 への負荷をより低減できるものと期待される。

\section{4 洗浄力及び乳化重合反応への応用}

\section{$4 \cdot 1$ 洗浄力測定}

Table 4 に分解性活性剂 1 ならびに指標石けんの人工

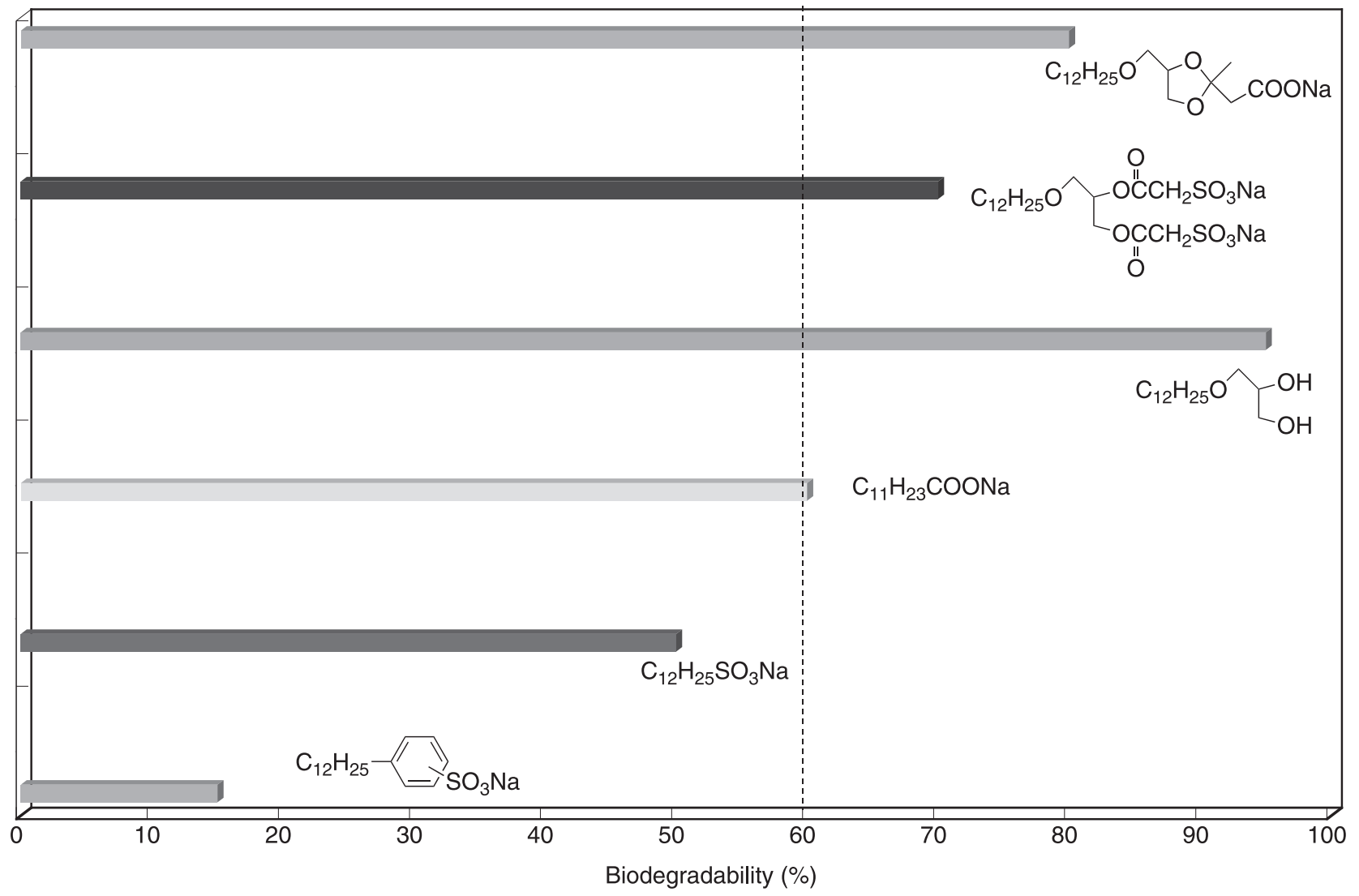

Fig. 2 Biodegradability chemocleavable surfactants 1a, 2a after 2 wk. 
Table 4 Detergency of chemocleavable surfactants 1.

\begin{tabular}{cccc}
\hline \multicolumn{2}{c}{ Compound } & \multicolumn{2}{c}{ Detergency (\%) } \\
& $\mathrm{R}$ & at $50 \mathrm{ppm}^{\mathrm{a})}$ & at $100 \mathrm{ppm}^{\mathrm{a})}$ \\
\hline 1a & $\mathrm{C}_{12} \mathrm{H}_{25}$ & 76.3 & 75.3 \\
1c & $\mathrm{C}_{16} \mathrm{H}_{33}$ & 78.8 & 71.4 \\
1d & $\mathrm{C}_{18} \mathrm{H}_{37}$ & 76.7 & 59.4 \\
\hline Reference soap & 77.2 & 63.1 \\
\hline
\end{tabular}

a) Total hardness of the examined solution as $\mathrm{CaCO}_{3}$.

污染布に対する洗浄力の結果を示した。試験は, JIS K3303に従って, 洗浄機 (Terg-O-Tometer, 回転数 $120 \mathrm{rpm}$ ）を用いて 10 分洗浄し，すすぎ 3 分を 2 回行っ た。洗浄前後の人工污染布の白色度を分光式色差計で測 定し, 洗浄力を評価した ${ }^{10)}$ 。

分解性活性剂 1 は, $50 \mathrm{ppm}$ の硬水中では指標石けん とほほ同等の洗浄力を示し, $100 \mathrm{ppm}$ の硬水中ではほと んどの活性剂で指標石けんを上回る洗浄力を示した。本 研究の範囲内では，高硬度の場合，短いアルキル鎖長を 有する分解性活性剂の洗浄力が高い傾向が認められた。

\section{$4 \cdot 2$ 乳化重合反応}

分解性活性剂 1a，2a を乳化剂とし，スチレンの乳化 重合反応を行った（Scheme 2)。スチレンと所定量の界 面活性剂を水 $100 \mathrm{~mL}$ に加え, 加熱し，500 rpm で擋汼 した。界面活性剂が溶解した後，擋拌を止め不活性ガス を 15 分間バブリングし，再び加熱摚找した。不活性ガ

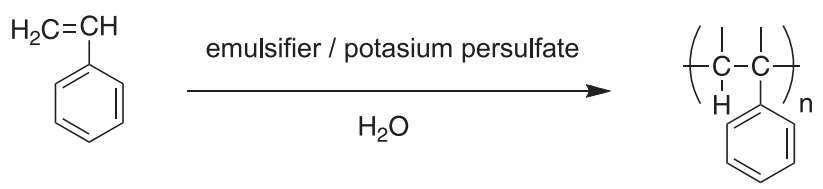

Scheme 2 Preparation of polystyrene.

ス雲囲気下，重合開始剤のペルオキソニ硫酸カリウムを 添加し $80^{\circ} \mathrm{C}$ で 2 時間半反応させた ${ }^{20)}$ 。

重合反応終了後, 1a の乳化解消処理は, 塩酸を添加し, 2aは，水酸化ナトリウムまたは塩酸を添加し，リファ レンスは, 一般的な乳化系の解消法である, 溶媒の添加 や塩析により行い, 水洗浄にてポリマーの単離を行っ た。Table 5, 6 に各種界面活性剤濃度, 乳化解消法, ポ リマーの回収率と得られたポリマーの性質について示し た。分散度, 重合度は, GPCにより,ナトリウム含有 量は, 原子吸光法で求めた。

分解性活性剤 1a，2a では，ポリスチレンの乳化重合 反応を一般的な界面活性剂よりも低濃度で合成すること ができた。また，分解性活性剤を用いた場合，酸または アルカリを添加することで簡便に乳化を解消でき，良好 な収率でポリマーを単離することができた。リファレン スの後処理に溶媒添加した場合ではポリマーが析出せ ず，単離できなかったが，飽和食塩水を添加した場合， 単離することができた。回収率が 100\%を超えているの は，ポリマー中に活性剤や塩などが残存しているためと 思われる。分解性活性剤 1a，2a の分散度は約 3 で，一

Table 5 Properties of polystyrene for $1 \mathrm{a}$

\begin{tabular}{|c|c|c|c|c|c|c|}
\hline Compound & $\begin{array}{l}\text { Conc. } \\
(\%)\end{array}$ & $\begin{array}{c}\text { Emulsion breaking } \\
\text { method }\end{array}$ & $\begin{array}{l}\text { Yield } \\
(\%)\end{array}$ & Dispersion $^{\text {a) }}$ & $\begin{array}{l}\text { Polymerization } \\
\text { degree }^{\text {a) }}\end{array}$ & $\begin{array}{c}\text { Na content }{ }^{\mathrm{b})} \\
(\%)\end{array}$ \\
\hline $1 a$ & 0.1 & $\mathrm{HCl}$ & 91 & 3.4 & 1180 & 0.05 \\
\hline $1 \mathrm{a}$ & 0.05 & $\mathrm{HCl}$ & 84 & 3.1 & 820 & $<0.01$ \\
\hline \multirow{3}{*}{$\begin{array}{l}\text { ドデカン酸 } \\
\text { ナトリウム }\end{array}$} & 1 & sat. $\mathrm{NaCl}$ aq & 105 & \multirow{3}{*}{3.6} & \multirow{3}{*}{2600} & 0.81 \\
\hline & 1 & ethanol & - & & & - \\
\hline & 1 & $\mathrm{HCl}$ & 105 & & & 0.16 \\
\hline
\end{tabular}

a) GPC.

b) Atomic absorption spectrophotometer.

Table 6 Properties of polystyrene for $2 \mathrm{a}$

\begin{tabular}{|c|c|c|c|c|c|c|}
\hline Compound & $\begin{array}{l}\text { Conc. } \\
(\%)\end{array}$ & $\begin{array}{c}\text { Emulsion breaking } \\
\text { method }\end{array}$ & $\begin{array}{l}\text { Yield } \\
(\%)\end{array}$ & Dispersion $^{\text {a) }}$ & $\begin{array}{l}\text { Polymerization } \\
\text { degree }^{\text {a) }}\end{array}$ & $\begin{array}{c}\mathrm{Na} \text { content } \mathrm{c}^{\mathrm{b})} \\
(\%)\end{array}$ \\
\hline $2 a$ & 0.1 & $\mathrm{HCl}$ & 84 & \multirow{2}{*}{3.1} & \multirow{2}{*}{670} & 0.11 \\
\hline $2 a$ & 0.1 & $\mathrm{NaOH}$ & 89 & & & 0.09 \\
\hline $\begin{array}{l}\text { ドデカン } \\
\text { スルホン酸 } \\
\text { ナトリウム }\end{array}$ & $\begin{array}{l}0.5 \\
0.5\end{array}$ & $\begin{array}{c}\text { sat. } \mathrm{NaCl} \text { aq } \\
\text { ethanol }\end{array}$ & $\begin{array}{c}103 \\
-\end{array}$ & $\begin{array}{l}3.1 \\
-\end{array}$ & $\begin{array}{c}1600 \\
-\end{array}$ & $\begin{array}{c}0.68 \\
-\end{array}$ \\
\hline
\end{tabular}

a) GPC.

b) Atomic absorption spectrophotometer. 
般的な活性剂と同等以上かもしくは小さい值となった が，重合度は，一般的な活性剤よりも小さかった。ナト リウム含有量は, 小さくなり純度の高いポリマーを得る ことができた。

\section{5 おわりに}

以上，1,3- ジオキソラン型及びエステル型の新規分解 性界面活性剂の合成と物性について研究を行った。本研 究で得られた成果を要約すると次のとおりである。

出発物質として，それ自身オレオケミカルズであり， また合成も容易な 1-O-アルキルグリセロールから 1,3ジオキソラン環を分子内に有する酸分解性カルボン酸塩 型界面活性剂とエステル結合を分解性部位として組み込 んだビス（スルホン酸塩）型界面活性剤を，特殊な試薬 や装置を用いることなく簡便な操作により高収率で合成 できることを明らかにした。合成した一連の活性剤につ いて，水溶液中での界面物性を評価し，界面物性に及ぼ す1,3- ジオキソラン環の効果などを明らかにした。これ らの分解性活性剤 1 は, 通常の石けんに比べて冷水に 溶け易く, 耐硬水性が高く, 界面物性も優れている上, 化学分解性に加えて良好な生分解性も備えていたことか ら，環境保全に配慮した洗剂の活性成分としての利用が 期待される。分解性活性剂 2 は, 良好な水溶性とミセ ル形成能を示し，またアルカリならびに酸の添加により 誘起される化学分解性に加え, 良好な生分解性を示すこ とを明らかにした。乳化重合反応で乳化剤として用いた 場合, 反応終了後, 酸またはアルカリを添加することに より，乳化系を解消でき塩濃度の低い純度の高いポリ マーを容易に単離することができた。

\section{文 献}

1) T. Kuwamura, H. Takahashi, Bull. Chem. Soc. Jpn., 45, 617 (1972).

2) D. A. Jaeger, Y. M. Sayed, J. Org. Clem., 58, 2619 (1993).

3) T. Kida, N. Morishima, A. Masuyama, Y. Nakatsuji, J. Am. Oil Chem. Soc., 71, 705 (1994)

4) G.-W. Wang, X.-Y. Yuan, Y.-C. Liu, X.-G. Lei, Q.-X. Guo, J. Am. Oil Chem. Soc., 72, 83 (1995).

5) A. Piasecki, A. Mayhew, J. Surfact. Deterg., 3, 59 (2000).

6) M. Iyer, D. G. Hayes, I. M. Harris, Langmuir, 17, 6816 (2001).
7) P.-E. Hellberg, C. G. van Ginkel, Tenside Surf. Det., 41, 278 (2004).

8) D. Ono, A. Masuyama and M. Okahara, J. Org. Chem., 55, 4461 (1990)

9) D. Ono, A. Masuyama, T. Tanaka and M. Okahara, Tenside Surfactants Deterg., 29, 412 (1992).

10) D. Ono, A. Masuyama, Y. Nakatsuji, M. Okahara, S. Yamamura and T. Takeda, J. Am. Oil Chem. Soc., 70, 29 (1993).

11) D. Ono, T. Tanaka, A. Masuyama, Y. Nakatsuji and M. Okahara, J. Jpn. Oil Chem. Soc. (YUKAGAKU), 42, 10 (1993).

12) D. Ono, S. Yamamura, M. Nakamura, T. Takeda, T. Tanaka, A. Masuyama and Y. Nakatsuji, J. Jpn. Oil Chem. Soc. (YUKAGAKU) , 42, 965 (1993).

13) D. Ono, S. Yamamura, M. Nakamura, T. Takeda, A. Masuyama and Y. Nakatsuji, J. Am. Oil Chem. Soc., 72, 853 (1995).

14) A. Masuyama, D. Ono, A. Yamamoto, T. Kida, Y. Nakatsuji and T. Takeda, J. Jpn. Oil Chem. Soc. (YU$K A G A K U$ ), 44, 446 (1995).

15) D. Ono, S. Yamamura, M. Nakamura, T. Takeda, J. Surfact. Deterg., 1, 201 (1998).

16) D. Ono, S. Yamamura, M. Nakamura, T. Takeda, J. Jpn. Oil Chem. Soc., 49, 785 (2000).

17) D. Ono, S. Yamamura, M. Nakamura, T. Takeda, J. Oleo Sic., 53, 89 (2004).

18) D. Ono, S. Yamamura, M. Nakamura, T. Takeda, $J$. Oleo Sic., 54, 51 (2005).

19) D. Ono, H. Sato, M. Shizuma, M. Nakamura, J. Oleo Sci., 59, 381 (2010).

20) D. Ono, Y. Takahashi, H. Sato, M. Shizuma, A. Masuyama, M. Nakamura, J. Oleo Sci., 60, 145 (2011).

21) M. Tsujimoto, Y. Toyama, Chem. Umschau., 29, 43 (1922).

22) Y. Toyama, Chem. Umschau., 32, 113 (1925).

23) L. M. Heilbron, W. M. Owens, J. Chem. Soc., 942 (1928).

24) H. Tsutsumi, A. Ishida, Yukagaku, 33, 270 (1984).

25) Y. Suzuki, H. Tsutsumi, Nippon Kagaku Kaishi, 1693 (1989).

26) M. J. Rosen, "In Surfactants and Interfacial Phenomena” Second Edition, p.118 (1989, John Wiley and Sons, New York).

27) W. Yano, W. Kimura, Yukagaku, 11, 138 (1962).

28) B. G. Wilkes and J. N. Wickert, Ind. Eng. Chem., 29, 1234 (1937).

29) A. Masuyama, A. Shindoh, D. Ono and M. Okahara, J. Am. Oil Chem. Soc. 66, 834 (1989). 